\title{
Bank Consolidation and Market Structure in Nigeria: Application of the Herfindahl-Hirschman Index
}

\author{
Bashorun Oladipo Titilayo ${ }^{1} \&$ Ojapinwa Taiwo Victor $^{2}$ \\ ${ }^{1}$ Department of Finance, University of Lagos, Lagos, Nigeria \\ ${ }^{2}$ Department of Economics, Lagos State University, Ojo-Lagos, Nigeria \\ Correspondence: Bashorun Oladipo Titilayo, Department of Finance, University of Lagos, Lagos, Nigeria. Tel: \\ 234-80-3777-4477. E-mail: baladsh@hotmail.com
}

Received: September 11, 2013

Accepted: November 14, 2013

Online Published: January 23, 2014

doi:10.5539/ijef.v6n2p235

URL: http://dx.doi.org/10.5539/ijef.v6n2p235

\begin{abstract}
This paper investigates the effect of bank consolidation in Nigeria on the structural characteristics of the banking market using the three-bank, five-bank and eight-bank concentration ratios as well as the Herfindahl-Hirschman Index (HHI) seven years after the conclusion of the first phase of the program. The result establishes a substantial increase in concentration for the post consolidation period with very high tendency to gravitate towards becoming a moderately concentrated market according to the USA merger guideline. Also, there is the emergence in 2012 , of eight top dominant banks controlling more than $75 \%$ of the Nigerian banking business especially in the total assets market. The implication of this finding is that there is the need to forestall collusive and anti-competitive practices by stepping up the oversight functions of the regulatory and supervisory agencies while reviewing periodically the hurdles for new entrants to the industry.
\end{abstract}

Keywords: consolidation, mergers, concentration, market share, total assets market

\section{Introduction}

Banks are known all over the world to play important economic roles such as the mobilization of deposits from the surplus units of societies, provision of credit facilities, developing and modernizing the payment system, transmitting the monetary policies of government as well as instilling public confidence in the financial system.

Mergers and acquisitions as organic growth strategy for Banks have gained sufficient ground as a result of globalization and improved technology thus making it possible for banks to enter new markets locally and internationally thereby enhancing global competitiveness. (Yadaw \& Kumar, 2005).

As financial consolidation is spreading across countries, the banking industry has been experiencing a fundamental change in market structure occasioned by the fierce competition among banks using state of the art technology as tool of competition to gain scale economies depending on the stage of economic development of the nations involved. Thus while bank consolidation in industrial countries like USA e.g. Citicorp and Travellers Group in 1998 and JP Morgan Chase and Bank One Corporation in 2004 evolved through the interplay of market forces, that of emerging economies has been forced by government through structural adjustment policy for the economy as a whole of which banking sector reform is a subset as a way of averting financial crisis in those economies (Lee \& Lee, 2002).

In Nigeria, the CBN announced in July, 2004, a 13-point reform agenda meant to promote sound, stable and efficient banking system and enhance its competitiveness in the global financial system. One of the 13 points, is the mandatory requirement that all commercial banks to raise the minimum capital base to N25billion latest by December 2005. The attempt to meet the minimum capital base triggered the Merger and Acquisition in the industry since this was specified as the only legal mode of consolidation in the guidelines issued by the CBN. By the terminal date of December 2005 given by CBN, only 25 out of 89 Banks were standing. During this first phase of the consolidation from July 2004 to December 2005 about 50 weak banks were merged with the existing ones. For instance 9 weak banks were merged to form Unity Bank late 2005. Also thirteen (13) Banks that could not meet the consolidation guidelines were allowed to exit the industry through a combination of purchase and assumption. So in the first phase, the system got rid of the weak banks that could precipitate systemic distress. 
By the conclusion of the first phase of the consolidation exercise, the industry began to experience re-alignment of market shares of individual banks based on strategy deployed. The second phase of the consolidation exercise began in 2008 and this drove mergers among sound and large banks in their quest for increased market share and to be in the forefront of banking business in Nigeria and Africa. Between 2011 and 2012, the acquisition of Oceanic bank, Intercontinental bank, Finbank and Equitorial trust bank by Ecobank, Access bank, FCMB and Sterling bank respectively were concluded and this increased the market shares of these acquiring banks considerably (see Tables 4-8).

Advocates of banking consolidation believe that it will produce bigger and healthier banks with better efficiency rating. Also it is expected to promote sound, stable and efficient banking system that will enhance competitiveness. However, critics fear that consolidation has the tendency to eliminate small banks resulting in reduced lending to small businesses as well as making a few mega banks to dominate the industry, with the consequence that the banking business will be less competitive (Mishkin, 2013).

Regulators expected from the onset that consolidation will transform the operational characteristics of the Nigeria banking system. One obvious consequence of Bank consolidation in Nigeria is that the number of banks reduced considerably from 89 in 2004 to 25 in 2005 and now to 21 in 2013 and it is expected, following the postulate of the structure conduct performance (SCP) hypothesis that this will translate into increased market concentration in the banking market.

The challenge of regulators and stakeholders in the industry is in the evaluation of the consolidation policy on market concentration, market competition, credit and operation risk as well as bank's profitability performance against the objectives and goals set in 2004. The objective of this paper is to expand the frontier of empirical literature by investigating and quantifying the structure of the Nigerian banking sector between 2005 and 2012 and gain an insight into how the market structure has hindered or enhanced competitive performance. In doing this, the author intends to use well known measures of market concentration like the three-bank, five-bank and eight-bank concentration ratios as well as the Hirschman-Herfindhal index (HHI) and to offer useful suggestions to stakeholders in line with our findings.

\section{Brief Background History}

According to Lemo (2005), ten top banks representing $11.25 \%$ of those in existence in 2004 had market shares in excess of $50 \%, 51 \%$ and $45 \%$ respectively for total assets, deposit liabilities and credits, suggestive of some oligopolistic tendencies with features of market power. Also a high proportion of the banks were too small in size compared to banks in other clime (Africa inclusive) with very huge overhead costs and over reliance on government patronage for their sources of funds. Furthermore, twenty-four or $27 \%$ of the banks in existence were either undercapitalized or insolvent or illiquid or having poor asset quality or poor corporate governance or all the ailments combined in the extreme cases. The low capital requirement made it easy for new entrants seeking economic rent and other interests not in alignment with furthering the monetary policies of government such as importing goods for re-sale through non-bank subsidiaries.

From the fore going it seems the bank consolidation exercise of 2005 in Nigeria was propelled by the high level of dissatisfaction with the old dispensation of banking system compared with the global best practice. A strong case was made for merger and acquisition in 2004 by the CBN as a way to enhance banking efficiency and to properly position the surviving banks in performance of developmental roles (Soludo, 2004) .

The summary of the CBN pronouncement in 2004 was that the Nigerian Banking Industry before 2005 was operating very far below its potentials when compared with other African countries and since the world had no room for fringe players and the industry, having failed to take moral suasion to voluntarily embark on consolidation in line with the global trend, this gave rise to the necessity for a regulatory induced mergers and acquisition of 2005 .

In order to comply with the directive of CBN on minimum capital requirement of N25 billion, banks in Nigeria employed strategies like; Capitalization of reserves, right issues for existing shareholders, initial public offers (IPOs) through the capital market, business mergers and in some cases outright acquisitions.

\section{Literature Review}

From available literature, consolidation occurs when two or more firms combine together to form a new one while the previous companies cease to continue existence. This situation, according to the Neo-classical economists, can arise due to profit maximizing behaviour of firms or through their desire to increase market power, thereby increasing the monopolistic characteristics of the market they operate in. According to Knickerbocker (1993), mergers can result from an 'oligopolistic reaction whereby if two firms in an oligopolistic 
industry merge, others might react by merging in turn (CantWell, 1992) thus setting up a chain reaction that can help in explaining the empirical evidence that seems to suggest that mergers as corporate behaviour have the tendency to happen in waves.

The condition under which the merger of large banks can be beneficial to the banking public is when the efficiency of the newly formed entities is enhanced resulting into lower prices per unit of service and increased service level (Berger \& Humphrey, 1997). While investigating the efficiency levels of consolidated banks and similarly non-consolidated ones, Rose (1995), found no evidence of benefit from merged banks while Altunbas et al. (2001) discovered merged banks to be less efficient than when they exist separately.

Bikker and Bos (2008), using a production function that is homogenous of degree one (i.e. twice continuously differentiable) affirms that banks as rational, economic agents interact with other economic agents like government and consumers and in so doing try to be productive and efficient. Productivity here means $\partial \mathrm{q} / \delta \mathrm{x} \geq 0$ and $\partial^{2} \mathrm{q} / \delta \mathrm{x}^{2} \leq 0$ while efficiency refers to the maximum output level given specified level of input.

The two contesting hypotheses that explain the market structure-performance relationship in industrial organisation studies are, The Structure-Conduct-Performance (SCP) paradigm and The Efficient Structure Hypothesis (ESH). The SCP paradigm posits that the level of competition weakens in a concentrated market, fostering "collusion" among few firms leading to abnormal profit for the industry (Bain,1951). In other words, concentration negatively impacts competition but is positively related with profit regardless of firm specific level of efficiency (Short, 1979; Bourke, 1989; Molyneux et al., 2004). This proposition is, however, challenged by the Efficient Structure Hypothesis on the ground that the SCP ignores bank regulation like entry and exit barriers and direct efficiency of firms. It introduces the concept of market share as a proxy for efficiency of firms and posits that an efficient bank (e.g., one with superior staff quality) will increase market share, increase market power and therefore increase profit. Here, market share is positively related to specific firm efficiency and this also explains the positive relationship between profit and concentration. In other words, there is a unidirectional causality running from efficiency to profit and market share. The shortcoming of this ESH stems from the fact that more efficient banks provide customers with loans at more competitive lower rates and deposits at higher rates leading to lowering of net margin and so efficiency measures may have negative correlation with net revenue from funds (NRFF).

It is reasonable to argue that neither the SCP nor the ESH can adequately explain bank competitive performance since size of banks, types of services, and modality for creating interphase with the market may affect competitive condition differently. This perhaps explains why researchers insist on the use of alternative measures of competition that include the non-structural models such as the Panza-Rosse Model (PR) and the Bresnahan and Lau Model.

Empirical studies on bank consolidation and market structure canvas three major positions. The first is where bank consolidation increases concentration and weakened competition as the case in the regional market of Spain. Fuentes and Sartre (1998) found that in the regional market of Spain, the level of competition was weak following consolidation thus lending support to the traditional view. Also Berg and Kim (1994) observed that for the Norwegian banking industry the conjectural variation is greater than one, implying that the industry is near monopoly with high degree of market power.

The second position is the situation where bank consolidation increases concentration without making competition to become weak. In this group, we have the Banking consolidation experience in the international market of Spain in 1990s as observed by Fuentes and Sartre (1998). Also Angelini and Ceterolli (2000) found no evidence of weak competition in Italy following banking industry consolidation. The banking consolidation in Korea, according to Lee and Lee (2004) increased market concentration but did not weaken competition during the period 1992-1997 but competition weakened over the period 1998-2002.

The third position is where bank consolidation increased concentration without having any significant effect on the level of competition as established by Hempell (2002), in the Germany consolidation experience when the period 1993-1995 is compared with the period 1996-1998 in spite of the increased concentration in the latter period following a decrease in the number of banks.

The review, so far, discusses a few of the theories explaining market structure following consolidation. These theories did not focus on how market structure will be measured. The SCP did not give indication of the size distribution of firms that will make the exercise of market power imminent. Also, the ESH posits that for as long as a bank is efficient, it will always post high profit notwithstanding the level of industry concentration and barriers to entry (Evanoff \& Fortier, 1988). Also the SCP hypothesis would hold true under condition of very stringent entry barriers. This paper looks at bank consolidation and its contribution to the emerging market 
structure in Nigeria over the period 2003 to 2012. Our methodology incorporates the descriptive, level and trend analyses of measures of market structural characteristics: the three-bank, five-bank, eight-bank concentration ratios as well as the Herfindhal-Hirschman Index (HHI).

\section{Methodology}

In this study, we are employing the $\mathrm{CR}_{\mathrm{k}}$ and the $\mathrm{HHI}$ as our measures of banking market concentration in line with other established empirical studies.

$\mathrm{CR}_{\mathrm{k}}$ is expressed as :

$$
C R_{k}=\sum_{i=1}^{k} M S_{i}
$$

and

$$
H H I=\sum_{i=1}^{N} M S_{i}^{2}
$$

where $\mathrm{CR}_{\mathrm{k}}$ represents market share of the largest $\mathrm{k}$ (banks) relative to total industry and $\mathrm{MS}_{\mathrm{i}}$ is the market share of each bank. According to the US Merger Guidelines, $\mathrm{HHI}<0.01$ implies a highly competitive market, $\mathrm{HHI}<0.1$ indicates an unconcentrated market, $0.1 \leq \mathrm{HHI}<1.8$ represents a moderately concentrated market and $\mathrm{HHI} \geq 1.8$ signifies a highly concentrated market. Increases in HHI will indicate increase in the market concentration and weakening competition, while a decrease is indicative of increase in market competition.

The variables chosen for this study, based on the intermediation approach to banking are, customer deposits, loans and advances and Total Assets.

\subsection{Data, Variables and Data Collection}

In this study, we will consider all the commercial banks in operation in Nigeria between year 2003 and 2012. The bank level data and all the proxies come from various annual audited reports and financial statements of the Banks. Except in some instances where there are missing values for some variables e.g. for reasons of cessation of business following acquisition, each bank is observed every year. Commercial banks are used as proxy for the Nigerian banking industry since the total share of business controlled relative to total financial market is in excess of 90 per cent over the sample period (Agusto \& Co, 2011). The variables chosen in determining the extent of market concentration over time in our sample banks include: customers deposit, total assets and loans/advances. Their inclusion is justified on the ground that they determine the extent of financial intermediation that the banks are engaged in.

\section{Deposits}

High performing banks are those with large customer deposit base with good mix (Naceur \& Goaied, 2001). Increased customers'deposits means increasing the funds available for use by the bank to finance diverse projects subject to acceptable risk rating.

\section{Total Asset}

The size of a bank is often determined by its total assets. As banks continue growing, some diseconomies of scale may set in especially if the system harbours administrative bottlenecks. Increased total asset can translate into market power and increased profit can result (Athanasoglou et al., 2005).

\section{Loans and Advances}

The profit of a bank is often determined by the volume and composition of its loan portfolio (Fries et al., 2002). The higher the ratio of performing loans to total loans, the higher the interest income generated. Performing loans generate revenue through interest and increase bank profits; hence a large portfolio of performing loans will imply improve profitability performance.

\section{Mpirical Results and Discussion}

The descriptive statistics of the variables of deposit, loans and total asset during the period 2003 to 2012 are summarized in Table 1. Banks like FBN, Access Bank, GT Bank, UBA and Zenith Bank assume mega status during the period under study and this account for the significant difference between the mean and median. 
Table 1. Descriptive statistics

\begin{tabular}{llll}
\hline & $\begin{array}{l}\text { N'llion } \\
\text { Deposit }\end{array}$ & $\begin{array}{l}\text { N'illion } \\
\text { Loans }\end{array}$ & $\begin{array}{l}\text { N'illion } \\
\text { Total Assets }\end{array}$ \\
\hline Mean & $326,007.40$ & $176,777.40$ & $584,137.30$ \\
Median & $187,793.00$ & $75,731.00$ & $303,008.50$ \\
Maximum & $2,171,807.00$ & $1,316,407.00$ & $3,366,529.00$ \\
Minimum & $2,163.00$ & $5,809.00$ & $20,933.00$ \\
Std. Dev. & $378,008.40$ & $223,717.40$ & $696,872.20$ \\
Skewness & 1.99 & 2.10 & 2.02 \\
Kurtosis & 7.31 & 7.97 & 6.95 \\
Jarque-Bera & 320.56 & 394.86 & 297.52 \\
Probability & 0.00 & 0.00 & 0.00 \\
Sum & $73,025,658.00$ & $39,598,143.00$ & $131,000,000.00$ \\
Sum Sq. Dev. & $3 . \mathrm{E}+13$ & $1 . \mathrm{E}+13$ & $1 . \mathrm{E}+14$ \\
Observations & 224 & 224 & 224 \\
\hline
\end{tabular}

Source: Authors Compilation from published accounts.

Kurtosis and Skewness for deposit, loans and total assets are greater than 3 and 1 respectively suggesting that our distribution appears normally distributed. This is further confirmed by the Jarque-Bera test which rejects the null hypothesis of the series not normally distributed at $1 \%$ level of significance. We conclude that deposits, loans and total assets, are normally distributed in Nigerian banks during the period covered by the study.

\subsection{Concentration Ratios}

We observe in Table 2, the emergence of eight large banks in year 2012 dominating the banking landscape in Nigeria. A bank is considered large here, if its market share relative to total market in any of the variables considered is in excess of 5\%. In 2012, these eight banks account for 77\% in total assets (2003: 56\%); $77 \%$ in total loans (2003: 47\%); and 75\% in customer deposit (2003: 54\%). Similarly, the five bank concentration ratio shows that five banks in 2012 control 62\% of total assets (2003: 46\%); 59\% of total loans (2003: 36\%); and 58\% of customer deposit (2003: 43\%) These significant increases in the concentration ratios reflect the changing structural characteristic of the industry.

Table 2. Concentration ratios

\begin{tabular}{llllllllll}
\hline & \multicolumn{3}{c}{ Deposit } & \multicolumn{3}{c}{ Loans } & \multicolumn{3}{c}{ Total Assets } \\
Year & CR3 & CR5 & CR8 & CR3 & CR5 & CR8 & CR3 & CR5 & CR8 \\
\hline $\mathbf{2 0 0 3}$ & $\mathbf{0 . 3 4 4 6}$ & $\mathbf{0 . 4 3 3 3}$ & $\mathbf{0 . 5 3 6 9}$ & $\mathbf{0 . 2 7 1 6}$ & $\mathbf{0 . 3 6 3 6}$ & $\mathbf{0 . 4 6 7 5}$ & $\mathbf{0 . 3 6 2 1}$ & $\mathbf{0 . 4 5 9 3}$ & $\mathbf{0 . 5 6 2}$ \\
2004 & 0.3911 & 0.4481 & 0.5406 & 0.3187 & 0.4034 & 0.4761 & 0.413 & 0.471 & 0.5711 \\
2005 & 0.3917 & 0.5662 & 0.7169 & 0.334 & 0.487 & 0.668 & 0.351 & 0.495 & 0.643 \\
2006 & 0.3818 & 0.527 & 0.6781 & 0.319 & 0.45 & 0.608 & 0.338 & 0.4 & 0.66 \\
2007 & 0.33 & 0.48 & 0.64 & 0.337 & 0.5 & 0.64 & 0.322 & 0.465 & 0.614 \\
2008 & 0.315 & 0.46 & 0.64 & 0.273 & 0.43 & 0.62 & 0.3 & 0.45 & 0.63 \\
2009 & 0.309 & 0.47 & 0.64 & 0.31 & 0.473 & 0.658 & 0.3266 & 0.52 & 0.686 \\
2010 & 0.3344 & 0.5109 & 0.6703 & 0.3449 & 0.5119 & 0.7016 & 0.3494 & 0.5485 & 0.7153 \\
2011 & 0.4032 & 0.5549 & 0.7092 & 0.404 & 0.5708 & 0.7575 & 0.4212 & 0.579 & 0.7236 \\
2012 & 0.4089 & 0.5795 & 0.7549 & 0.4299 & 0.5916 & 0.7747 & 0.4596 & 0.6237 & 0.7714 \\
\hline
\end{tabular}

Source : Authors Compilation from published accounts. 


\subsection{Herfindahl-Hirschman Index (HHI)}

The various concentration ratios (CRk) do not account completely for the total number of banks in the industry when measuring concentration at any point in time. This is a major disadvantage as issues of concentration and competition are directly related to the number of banks in the industry and their relative sizes. The HHI takes care of this problem. Table 3 provides a summary of HHI for the Nigerian banking industry in the period under consideration using customer deposit, loans and total assets as variables of interest.

Table 3. Herfindahl-hirschman index

\begin{tabular}{llll}
\hline year & Deposit & Loans & Total Assets \\
\hline 2003 & 0.0572 & 0.0411 & 0.0591 \\
2004 & 0.06034 & 0.05732 & 0.0641 \\
2005 & 0.07975 & 0.0708 & 0.069 \\
2006 & 0.0796 & 0.0619 & 0.0704 \\
2007 & 0.0678 & 0.0684 & 0.0632 \\
2008 & 0.0658 & 0.063 & 0.0637 \\
2009 & 0.0651 & 0.0675 & 0.07717 \\
2010 & 0.07028 & 0.07533 & 0.07797 \\
2011 & 0.084 & 0.09075 & 0.0878 \\
2012 & 0.0893 & 0.0966 & 0.098 \\
\hline
\end{tabular}

Source: Authors Compilation from published accounts.

The values of HHI for all major variables increase over the period of analysis except for the observed dip in 2007 to 2009; the period that coincides with the global financial crisis. The evidence suggests that in the pre-consolidation era $(2003 / 2004)$, the Nigerian banking industry was an unconcentrated market $(\mathrm{HHI}<0.1)$ in the deposit, loans and total asset market. In the post consolidation period 2005-2012, there is a gradual and steady march towards being moderately concentrated especially in the loans and total asset market.

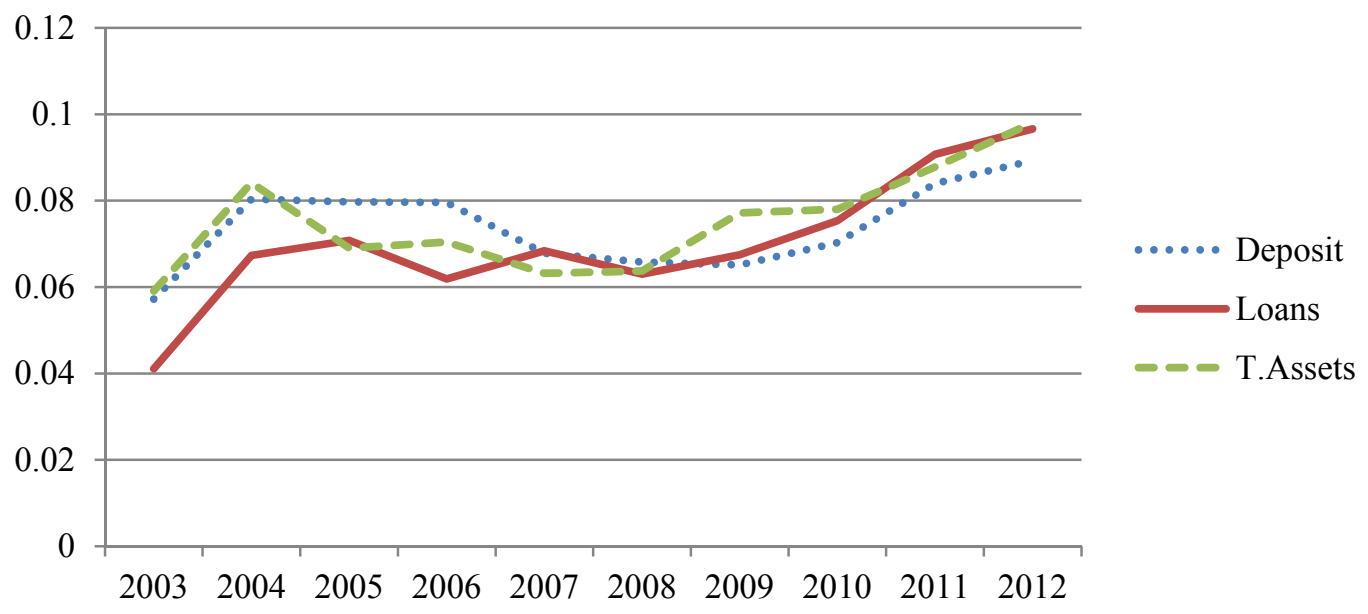

Figure 1. Herfindahl-hirschman index

Among the three segments presented in Table 3 above, there is a greater competition in the deposit market since the segment records the least HHI Figure 1 represents line graphs capturing the trend of the Herfindahl-Hirschman Index.

Tables 4 and 5 below indicate the size of Nigeria banks in absolute and relative terms for total industry as well as top five and top eight banks in the post and pre-consolidation era. 
Table 4. Size indicators

\begin{tabular}{|c|c|c|c|c|c|c|c|c|c|c|c|c|c|}
\hline & \multirow{3}{*}{ HHI } & \multicolumn{6}{|c|}{ 2012(post-consolidation) } & \multicolumn{6}{|c|}{ 2003(pre-consolidation) } \\
\hline & & \multicolumn{2}{|c|}{ Industry } & \multicolumn{2}{|c|}{ Top five banks } & \multicolumn{2}{|c|}{ Others } & \multicolumn{2}{|c|}{ Industry } & \multicolumn{2}{|c|}{ Top five } & \multicolumn{2}{|c|}{ Others } \\
\hline & & N'billion & $\%$ & N'billion & $\%$ & N'billion & $\%$ & N'billion & $\%$ & N'billion & $\%$ & N'billion & $\%$ \\
\hline SHF & 0.0884 & 2,686 & 100 & 1,550 & 58 & 1,136 & 42 & 198 & 100 & 95 & 48 & 103 & 52 \\
\hline $\begin{array}{l}\text { Local } \\
\text { currency } \\
\text { deposit }\end{array}$ & 0.0893 & 14,502 & 100 & 7,701 & 53 & 6,805 & 47 & 1,229 & 100 & 721 & 59 & 508 & 41 \\
\hline $\begin{array}{l}\text { Total } \\
\text { loans and } \\
\text { advances }\end{array}$ & 0.0966 & 7,547 & 100 & 4,116 & 55 & 3,431 & 46 & 505 & 100 & 224 & 44 & 281 & 56 \\
\hline $\begin{array}{l}\text { Gross } \\
\text { earnings }\end{array}$ & 0.0736 & 2,307 & 100 & 1,162 & 50 & 1,145 & 50 & 298 & 100 & 146 & 49 & 152 & 51 \\
\hline $\begin{array}{l}\text { Total } \\
\text { assets }\end{array}$ & 0.098 .0 & 23,514 & 100 & 13,435 & 57 & 10,079 & 43 & 2,342 & 100 & 1,258 & 54 & 1,084 & 46 \\
\hline
\end{tabular}

Source: Authors Compilation from published accounts.

Table 5. Size indicators

\begin{tabular}{|c|c|c|c|c|c|c|c|c|c|c|c|c|c|}
\hline & \multirow{3}{*}{ HHI } & \multicolumn{6}{|c|}{ 2012(post-consolidation) } & \multicolumn{6}{|c|}{ 2003(pre-consolidation) } \\
\hline & & \multicolumn{2}{|c|}{ Industry } & \multicolumn{2}{|c|}{ Top eight banks } & \multicolumn{2}{|c|}{ Others } & \multicolumn{2}{|c|}{ Industry } & \multicolumn{2}{|c|}{ Top eight banks } & \multicolumn{2}{|c|}{ Others } \\
\hline & & N'billion & $\%$ & N'billion & $\%$ & N'billion & $\%$ & N'billion & $\%$ & N'billion & $\%$ & N'billion & $\%$ \\
\hline SHF & 0.0884 & 2,686 & 100 & 2,008 & 75 & 678 & 25 & 198 & 100 & 123 & 62 & 75 & 38 \\
\hline $\begin{array}{l}\text { Local } \\
\text { currency } \\
\text { deposit }\end{array}$ & 0.0893 & 14,506 & 100 & 10,880 & 75 & 3,626 & 25 & 1,229 & 100 & 866 & 71 & 363 & 29 \\
\hline $\begin{array}{l}\text { Total } \\
\text { loans and } \\
\text { advances }\end{array}$ & 0.0966 & 7,547 & 100 & 5,811 & 77 & 1,736 & 23 & 505 & 100 & 299 & 59 & 205 & 41 \\
\hline $\begin{array}{l}\text { Gross } \\
\text { earnings }\end{array}$ & 0.0736 & 2,307 & 100 & 1,535 & 67 & 772 & 33 & 298 & 100 & 190 & 64 & 108 & 36 \\
\hline $\begin{array}{l}\text { Total } \\
\text { assets }\end{array}$ & 0.098 & 23,514 & 100 & 18,106 & 77 & 5,408 & 23 & 2,342 & 100 & 1,581 & 67 & 761 & 33.5 \\
\hline
\end{tabular}

Source: Authors Compilation from published accounts.

From the above table, there seems to be the emergence in 2012 of eight dominant banks post consolidation controlling $75 \%, 77 \%$ and $77 \%$ respectively of deposit, loans/ advances and total assets compared to 2003 (pre-consolidation) where they control respectively $71 \%, 59 \%$ and $67 \%$ in deposit, loans and total assets. This development has the tendency towards confirming the fear expressed by Mishikin (2013) that a few banks may dominate the industry and make the latter less competitive.

\section{Summary, Conclusion and Policy Implication}

This paper sets out to investigate and quantify the changing structure of Nigeria banks in the pre and post consolidation period and determine if consolidation has impacted on the degree of concentration and competition in the market. The overall results suggest unconcentrated banking market in Nigeria (going by the US merger guidelines), with increasing and systematic slide towards becoming moderately concentrated especially in the total asset market. It is not clear whether the observed increase in concentration will weaken competition conclusively as suggested by the SCP hypothesis. This will need to be corroborated by other non-structural measures of competitive conduct like the Panzar-Rosse (1987) methodology (the H-statistics). This is suggested for further studies to be able to make conclusive remarks on the impact of industry concentration on competitive conduct of the Nigerian banks.

With eight top dominant banks appearing on the Nigerian banking scene, there is the need to pro-actively guide against collusive and anti-competitive practices by stepping up the oversight functions of the regulatory and 
supervisory agencies. It may also be beneficial to review during the quarterly monetary policy committee meeting of CBN, the hurdles for new entrants to the industry and go on to establish the optimal number of banks required in Nigeria.If found to be less than the current twenty-one, this may provide the trigger for yet another round of bank consolidation exercise. This is another area that may warrant further research.

\section{References}

Agusto, \& Co. (2011). Nigerian Banking Industry report (pp. 35).

Altunbas, Y., Gardener, E. P., Molyneux, P., \& Moore, B. (2001). Efficiency in European banking. European Economic Review, 45, 1931-1955. http://dx.doi.org/10.1016/S0014-2921(00)00091-X

Angelini, P., \& Cetorelli, N. (2000). Bank competition and regulatory reform: The case of the Italian banking industry. Temi di discussion delseruziostudi, Bancad'Italia, N, 380, October.

Athanasoglou, P. P., Brissimis, S. N., \& Delis, M. D. (2005). Bank-specific, industry-specific and macroeconomic determinants of bank profitability. Bank of Greece working paper No. 25.

Bain, J. S. (1951). Relation of profit rate to industry concentration: American manufacturing 1936-1940. Quarterly Journal of Economics, 65, 293-324. http://dx.doi.org/10.2307/1882217

Berg, S. A., \& Kim, N. (1994). Oligopolistic interdependence and the structure of production in banking: An empirical evaluation. Journal of Money, Credit and Banking, 26(2), 309-322. http://dx.doi.org/10.2307/2077911

Berger, A. N., \& Humphrey, D. B. (1997). Efficiency of financial institutions: Internaitonal survey and directions for future research. European Journal of Operations Research, 98, 175-212. http://dx.doi.org/10.1016/S0377-2217(96)00342-6

Bikker, J. A., \& Bos, J. W. B. (2008). Bank performance, a theoretical and empirical framework for the analysis of profitability, competition and efficiency. New York, USA: Routledge.

Cantwell, J. (1992). Multinational investment in modern Europe. Aldershot: Edward Elgar.

Evanoff, D., \& Fortier, D. L. (1988). Revaluation of the Structure-Conduct-Performance Paradigm in Banking. Journal of Financial Services Research, 1, 277-294. http://dx.doi.org/10.1007/BF00114854

Fries, S., Neven, D., \& Seabright, P. (2002). Bank performance in transition Economies. European Bank for Reconstruction and Development working paper, No. 76.

Fuentes, I., \& Sarre, T. (1998). Implications of restructuring in the banking industry: The case of Spain (Vol. 7, pp. 98-120). BIS Conference Papers.

Goldberg, L. G., \& Rai, A. (1996). The structure performance relationship for European banking. Journal of Banking and Finance, 20, 745-771. http://dx.doi.org/10.1016/0378-4266(95)00021-6

Knickerbocker, F. T. (1993). Oligopolistic reaction and multinational enterprise. Division of Research, Harvard Business School, Boston.

Lee, \& Lee. (2004). Bank consolidation and bank competition: An empirical analysis of the Korean banking industry. Economic Papers, 8(1).

Lemo, T. (2005). Regulatory oversight and stakeholders protection. A paper presented at the BGL mergers and acquisitions interactive seminar, held at Eko Hotels \& Suites, Victoria Island on June 24.

Mishkin, F. (2013). The Economics of money, banking and financial markets (10th ed.). Essex CM20 2JE England: Pearson Education Inc.

Naceur, S. B., \& Goaied, M. (2001). The determinants of the Tunisian deposit banks' performance. Applied Financial Economics, 11, 317-319. http://dx.doi.org/10.1080/096031001300138717

Panzar, J., \& Rosse, J. (1987). Testing for monopoly equilibrium. Journal of Industrial Economics, 35, 443-456. http://dx.doi.org/10.2307/2098582

Rose, P. S. (1995). The distribution of outcomes from corporate mergers: The case of commercial banking. Journal of Accounting, Auditing and Finance, 10, 343-364.

Yadaw, A. K., \& Kumar, B. R. (2005). Role of organization culture in mergers and acquisitions. SCMS Journal of Management, 2(3), 51-63. 


\section{Copyrights}

Copyright for this article is retained by the author(s), with first publication rights granted to the journal.

This is an open-access article distributed under the terms and conditions of the Creative Commons Attribution license (http://creativecommons.org/licenses/by/3.0/). 